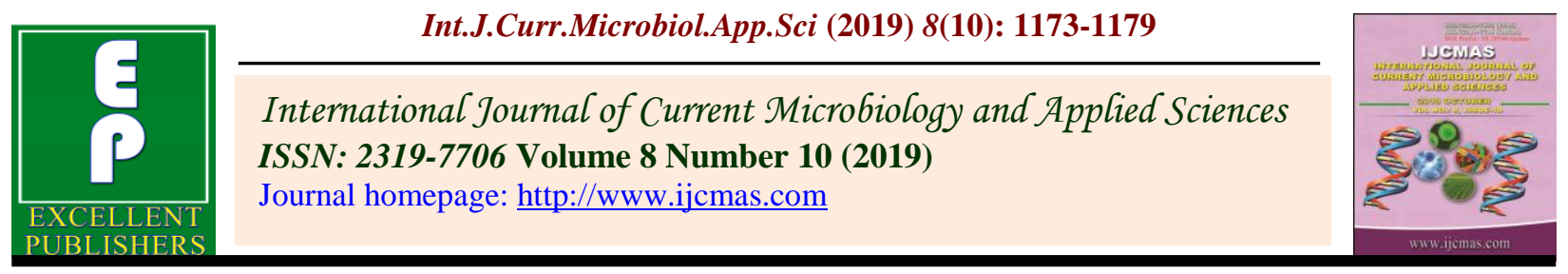

\title{
Effect of Different Levels of Nitrogen and Weed Management Practices on Weed Parameters of Gaillardia (Gaillardia pulchella Foug.) under Hyderabad Conditions
}

\author{
G. Prashamsha ${ }^{1 *}$, P. Prasanth ${ }^{2}$ and Seenivasan Natarajan ${ }^{3}$ \\ ${ }^{1}$ Department of FLA, College of Horticulture, SKLTSHU, Rajendranagar, Hyderabad, India \\ ${ }^{2}$ Floricultural Research Station, Rajendranagar, Hyderabad, India \\ ${ }^{3}$ College of Horticulture, SKLTSHU, Mojerla, India \\ *Corresponding author
}

\section{A B S T R A C T}

\begin{tabular}{|c|c|}
\hline $\begin{array}{l}\text { Ke y w o r d s } \\
\text { Gaillardia, } \\
\text { Nitrogen, Weeds, } \\
\text { Mulching, Weed } \\
\text { control efficiency }\end{array}$ & $\begin{array}{l}\text { Weed management in crops through hand weeding is facing a tough challenge in many } \\
\text { developing countries like India where workers are migrating from rural to urban areas in } \\
\text { search of better job and lifestyle opportunities. Manual weeding option is facing acute } \\
\text { shortage of labour. The present investigation was therefore carried out to study the effect } \\
\text { of different levels of nitrogen and weed management practices on weed parameters of } \\
\text { gaillardia (Gaillardia pulchella Foug.) under Hyderabad conditions and it was carried out }\end{array}$ \\
\hline Article Info & \\
\hline $\begin{array}{l}\text { Accepted: } \\
\text { 10 September } 2019 \\
\text { Available Online: } \\
10 \text { October } 2019\end{array}$ & $\begin{array}{l}\text { Minimum weed count per square meter ( } 15.59 \text { and } 2.16) \text {, dry weight of weeds }(2.34 \mathrm{~g} \text { and } \\
0.71 \mathrm{~g}) \text { was observed in } 180 \mathrm{~kg} \text { N/ha and mulching with black and silver polythene mulch. } \\
\text { Weed control efficiency was maximum }(62.70 \% \text { and } 94.944 \%) \text { in treatment } 180 \mathrm{~kg} \mathrm{~N} / \mathrm{ha} \\
\text { and mulching with black and silver polythene mulch. }\end{array}$ \\
\hline
\end{tabular}

\section{Introduction}

Gaillardia pulchella, also known as blanket flower or fire-wheel is one of the important bedding and loose flower plants grown across the globe. It is hardy, short-lived perennial and grown under a variety of soil and climatic conditions. The genera have over two dozen species which are mostly native to North America (Bailey, 1947). As a bedding plant, it is grown in pots, mixed containers and borders for short time display while the whole flowering stem is marketed as a cut flower for bouquets (Armitage, 1992). Gaillardia provides sizzling summer color to the garden with striking blooms in combinations of red, yellow and orange offset by deep brown centers.

Success in any crop production technology depends on thorough weed management practices. Weeds are of special significance when the gaillardia is grown in the field for commercial production. Weeds cause heavy 
damage to this crop by competing with main plants for water, nutrients, light and space besides acting as alternate hosts to a number of pathogens and pests. Hence, for protection of this commercially important crop, proper weed control is of utmost significance. Cultural and use of chemical are the most effective methods as compared to the physical method. Black polyethylene mulches offer complete weed control and increase the temperature of the air and soil environment close to the plant as a result of the mulch's absorption of solar radiation (Jenni et al., 2004).Herbicides constitute a highly efficient technique for controlling weeds hence increasing yields, improving quality and reducing labour in crop production (Sill, 1982).

Therefore, the present investigation was carried out to assess the effect of different levels of nitrogen and weed management practices on weed parameters of gaillardia crop.

\section{Materials and Methods}

The present experiment was conducted at Floricultural Research station, Agricultural Research Institute, Rajendranagar, Hyderabad. It was laid out in Factorial Randomized Block Design comprising of twenty treatments with cultivar Local Red (yellow tip) with three replications. The treatments consisted of four nitrogen levels i.e. $0 \mathrm{Kg} \mathrm{N} / \mathrm{ha}\left(\mathrm{N}_{1}\right), 75 \mathrm{Kg}$ $\mathrm{N} / \mathrm{ha}\left(\mathrm{N}_{2}\right), 150 \mathrm{Kg} \mathrm{N} / \mathrm{ha}\left(\mathrm{N}_{3}\right), 180 \mathrm{Kg} \mathrm{N} / \mathrm{ha}$ $\left(\mathrm{N}_{4}\right)$ and five weed management practices i.e, Black and silver polythene mulch (40 microns) $\left(\mathrm{T}_{1}\right)$ Paddy straw mulch $\left(\mathrm{T}_{2}\right)$, Pendimethalin $1 \mathrm{~kg}$ a.i. / ha + weeding 30 DAT $\left(\mathrm{T}_{3}\right)$, Weed free control $\left(\mathrm{T}_{4}\right)$, Control (without weeding) $\left(\mathrm{T}_{5}\right)$. The size of the size of the bed was $1.8 \times 0.9 \mathrm{~m}$ with a spacing $30 \times 45 \mathrm{~cm}$. Forty five days old seedlings were transplanted on $2^{\text {nd }}$ fortnight of September and all the recommended package of practices were adopted systematically.
To record observations on weed count, weeds removed from $0.25 \mathrm{~m}^{2}$ area in a randomly marked spots in each plot at 20 days interval after application was considered. After counting, the weeds they were oven dried at $65^{\circ}-70^{\circ}$ Cfor $48 \mathrm{hrs}$ and dry weight were recorded. Weed control efficiency (W.C.E) was calculated on dry weight basis by adopting the following formula (Mani et al., 1976).

$\mathrm{WCE}=\frac{D W C-D W T}{D W C} \times 100$

Where,

WCE $=$ Weed control efficiency

DWC $=$ Dry weight of weeds in weedy check plot

DWT $=$ Dry weight of weeds in treated plot

Five plants were selected randomly from each treatment, tagged and recorded growth parameters viz., number of weeds per square meter, weed control efficiency and dry weight of weeds. The observations were statistically analyzed.

\section{Results and Discussion}

The data related to number of weeds per square meter, weed control efficiency and dry weight of weeds are presented in table 1,2 and 3.

\section{Weed parameters}

\section{Number of weeds per meter square}

Data on weed count were recorded at 20, 40 DAT and is presented in Table 1.

\section{DAT}

At 20 DAT the treatment $\left(\mathrm{N}_{4}\right) 180 \mathrm{~kg} \mathrm{~N} / \mathrm{ha}$ (19.09) recorded minimum no. of weeds which was on par with $\left(\mathrm{N}_{2}\right) 150 \mathrm{~kg} \mathrm{~N} / \mathrm{ha}$ 
(19.86) were significantly superior to $\left(\mathrm{N}_{1}\right) 0$ $\mathrm{kg} \mathrm{N} / \mathrm{ha}$ (21.06). The highest weed count was noticed in $\left(\mathrm{N}_{2}\right) 75 \mathrm{~kg}$ nitrogen/ha (22.39).

It is quite evident from the data that significant differences were observed among the different weed control treatments for weed count at 20 DAT. It is quite evident from the data that at early stage of crop growth i.e., 20 DAT, the mulching with $\left(\mathrm{T}_{1}\right)$ black and silver polythene mulch (6.33) significantly reduced the weed population as compared to plots where other treatments were imposed i.e. pendimethalin @ $1 \mathrm{~kg}$ a.i. / ha + weeding 30 DAT (10.08), $\left(\mathrm{T}_{2}\right)$ paddy straw mulch (15.33) and $\left(\mathrm{T}_{4}\right)$ weed free control (34.08) and maximum was recorded with ( $\left.\mathrm{T}_{5}\right)$ control (without weeding) (37.12). Similar results are obtained with Jadhav et al., (2018)

\section{DAT}

At 40 DAT least no. of weeds was noticed in $\left(\mathrm{N}_{4}\right) 180 \mathrm{~kg} \mathrm{~N} / \mathrm{ha}(15.59)$ followed by $\left(\mathrm{N}_{2}\right) 150$ $\mathrm{kg} \mathrm{N} / \mathrm{ha}$ (16.60), $\left(\mathrm{N}_{1}\right) 0 \mathrm{~kg} \mathrm{~N} / \mathrm{ha}$ (17.33), $\left(\mathrm{N}_{2}\right) 75 \mathrm{~kg} \mathrm{~N} / \mathrm{ha}$ (18.66). The highest weed count was noticed in $\left(\mathrm{N}_{2}\right) 75 \mathrm{~kg} \mathrm{~N} / \mathrm{ha}$ (18.66). Weed count was lower with increase in nitrogen level due to uptake of nitrogen was maximum in Gaillardia plant with good growth than the weeds.

Data recorded at 40 DAT, treatment $\left(\mathrm{T}_{1}\right)$ black and silver polythene mulch (2.16) recorded lower weed count and followed by treatment $\left(\mathrm{T}_{2}\right)$ pendimethalin at $1 \mathrm{~kg}$ a.i. /ha + weeding 30 DAT (7.68), $\left(\mathrm{T}_{2}\right)$ paddy straw mulch (8.33) and $\left(\mathrm{T}_{4}\right)$ weed free control (24.08) and higher weed count was recorded with $\left(\mathrm{T}_{5}\right)$ control (without weeding) (42.99).

Among the different treatments, very less weed infestation was recorded under black and silver polythene mulch. This might be due to the black colour of the polythene absorbed all the incident radiation itself. Therefore no light penetration occurred through the polythene mulch which ultimately checks the weed seed germination and growth. Similar observations were reported in rose by Kumar and Chakraborty (2010).

Spreading habit of gaillardia controlled maximum weeds within in $40 \mathrm{DAT}$. Due to the spreading habit there was less competition of weeds for sunlight and space.

\section{Weed Control Efficiency (WCE \%)}

Weed control efficiency (WCE) can be worked out considering dry matter production of weeds. Data on weed control efficiency under different nitrogen levels, weed management practices and interaction have been given in table 2 and figure 1.

The results revealed that nitrogen at different levels has no significant influence on Weed control efficiency of Gaillardia. Among various weed control treatments, WCE was found to be significantly higher in treatment $\left(\mathrm{T}_{1}\right)$ black and silver polythene mulch $(94.94$ $\%$ ) followed by $\left(\mathrm{T}_{3}\right)$ pendimethalin at $1 \mathrm{~kg}$ a.i. /ha + weeding 30 DAT (78.79\%).

However, the lowest weed control efficiency $(0.00 \%)$ was observed in $\left(\mathrm{T}_{5}\right)$ control (without weeding) due to maximum number of weeds.

Among all the treatment maximum WCE was recorded in treatment mulching with black and silver polythene mulch. Similar results were also reported by Shalini and Patil (2006) in gerbera, Chawla (2008) in African marigold, Solaiman et al., (2008) in Aster, Kumar and Chakraborty (2010) in rose.

Higher weed control efficiency under these treatments can accounted to lower dry weight of weeds in these treatments. The lowest weed control efficiency was observed in control due to no control of weeds. 
Table.1 Effect of nitrogen levels, weed management practices and their interaction on number of weeds per square meter of Gaillardia Cv. Local red (with yellow tip)

\begin{tabular}{|c|c|c|c|c|c|c|c|c|c|c|}
\hline \multirow[t]{3}{*}{ Treatment } & \multicolumn{10}{|c|}{ Number of weeds/ $\mathbf{m}^{2}$} \\
\hline & \multicolumn{5}{|c|}{20 DAT } & \multicolumn{5}{|c|}{40 DAT } \\
\hline & $\mathbf{N}_{1}$ & $\mathbf{N}_{2}$ & $\mathbf{N}_{3}$ & $\mathrm{~N}_{4}$ & Mean & $\mathrm{N}_{1}$ & $\mathbf{N}_{2}$ & $\mathbf{N}_{3}$ & $\mathbf{N}_{4}$ & Mean \\
\hline$T_{1}$ & 7.00 & 6.68 & 6.00 & 5.67 & $6.33^{a}$ & 2.66 & 2.33 & 2.00 & 1.67 & $2.16^{a}$ \\
\hline $\mathbf{T}_{2}$ & 17.68 & 15.66 & 14.33 & 13.67 & $15.33^{c}$ & 9.66 & 8.33 & 7.00 & 5.66 & $7.68^{b}$ \\
\hline $\mathbf{T}_{3}$ & 11.65 & 10.01 & 9.66 & 9.00 & $10.08^{b}$ & 10.00 & 8.00 & 7.67 & 7.68 & $8.33^{b}$ \\
\hline $\mathbf{T}_{4}$ & 35.66 & 34.66 & 33.66 & 32.33 & $34.08^{d}$ & 26.10 & 24.33 & 23.68 & 22.33 & $24.08^{c}$ \\
\hline$T_{5}$ & 40.00 & 38.33 & 35.67 & 34.81 & $37.12^{e}$ & 45.02 & 43.67 & 42.66 & 40.63 & $42.99^{d}$ \\
\hline Mean & $22.39^{b}$ & $21.06^{b}$ & $19.86^{\mathrm{a}}$ & $19.09^{a}$ & & $18.66^{c}$ & $17.33^{b}$ & $16.60^{b}$ & $15.59^{\mathrm{a}}$ & \\
\hline $\begin{array}{l}\text { For comparing } \\
\text { the means of }\end{array}$ & \multicolumn{3}{|c|}{ SEm \pm} & \multicolumn{2}{|c|}{ CD @ 5\% } & \multicolumn{3}{|c|}{ SEm \pm} & \multicolumn{2}{|c|}{ CD @ 5\% } \\
\hline N (Factor A) & \multicolumn{3}{|c|}{0.64} & \multicolumn{2}{|c|}{1.85} & \multicolumn{3}{|c|}{0.32} & \multicolumn{2}{|c|}{0.94} \\
\hline T (Factor B) & \multicolumn{3}{|c|}{0.72} & \multicolumn{2}{|c|}{2.07} & \multicolumn{3}{|c|}{0.36} & \multicolumn{2}{|c|}{1.10} \\
\hline $\mathbf{N} \mathbf{X}$ & \multicolumn{3}{|c|}{1.44} & \multicolumn{2}{|c|}{ NS } & \multicolumn{3}{|c|}{0.73} & \multicolumn{2}{|c|}{ NS } \\
\hline
\end{tabular}

Table.2 Effect of nitrogen levels, weed management practices and their interaction on weed control efficiency of Gaillardia $\mathrm{Cv}$. Local red (with yellow tip)

\begin{tabular}{|c|c|c|c|c|c|}
\hline \multirow[t]{2}{*}{ Treatment } & \multicolumn{5}{|c|}{ WCE \% at 40DAT } \\
\hline & $\mathbf{N}_{1}$ & $\mathbf{N}_{2}$ & $\mathbf{N}_{3}$ & $\mathbf{N}_{4}$ & Mean \\
\hline$T_{1}$ & 94.29 & 94.52 & 95.32 & 95.61 & $94.94^{\mathrm{a}}$ \\
\hline $\mathbf{T}_{2}$ & 74.59 & 76.49 & 78.56 & 80.35 & $77.50^{b}$ \\
\hline $\mathbf{T}_{3}$ & 76.19 & 78.55 & 79.37 & 81.05 & $78.79^{b}$ \\
\hline $\mathbf{T}_{4}$ & 51.83 & 54.85 & 55.08 & 56.50 & $54.52^{c}$ \\
\hline $\mathbf{T}_{5}$ & 0 & 0 & 0 & 0 & 0 \\
\hline Mean & 59.34 & 60.88 & 61.66 & 62.70 & \\
\hline $\begin{array}{c}\text { For comparing } \\
\text { the means of }\end{array}$ & \multicolumn{3}{|c|}{ SEm \pm} & \multicolumn{2}{|c|}{ CD@ $@ 5 \%$} \\
\hline N (Factor A) & \multicolumn{3}{|c|}{1.06} & \multicolumn{2}{|c|}{ NS } \\
\hline $\mathbf{T}$ (Factor B) & \multicolumn{3}{|c|}{1.19} & \multicolumn{2}{|c|}{3.41} \\
\hline N X T & \multicolumn{3}{|c|}{2.38} & \multicolumn{2}{|c|}{ NS } \\
\hline
\end{tabular}


Table.3 Effect of nitrogen levels, weed management practices and their interaction on dry weight of weeds

\begin{tabular}{|c|c|c|c|c|c|c|c|c|c|c|}
\hline \multirow[t]{3}{*}{ Treatment } & \multicolumn{10}{|c|}{ Dry weight of weeds $\left(\mathrm{g} / \mathrm{m}^{2}\right)$} \\
\hline & \multicolumn{5}{|c|}{20 DAT } & \multicolumn{5}{|c|}{40 DAT } \\
\hline & N1 & $\mathbf{N 2}$ & N3 & N4 & Mean & N1 & N2 & N3 & N4 & Mean \\
\hline T1 & 2.14 & 2.42 & 1.80 & 1.57 & 1.98 & 0.77 & 0.80 & 0.66 & 0.57 & 0.71 \\
\hline $\mathbf{T 2}$ & 5.08 & 6.38 & 4.52 & 4.27 & 5.06 & 3.32 & 3.67 & 2.89 & 2.62 & 3.13 \\
\hline T3 & 3.35 & 3.79 & 3.27 & 3.15 & 3.39 & 3.20 & 3.29 & 2.91 & 2.70 & 3.02 \\
\hline T4 & 9.46 & $\begin{array}{c}10.0 \\
1\end{array}$ & 9.32 & 8.94 & 9.43 & 6.19 & 6.94 & 6.38 & 5.80 & 6.33 \\
\hline T5 & 0 & 0 & 0 & 0 & $\mathbf{0}$ & 0 & 0 & 0 & 0 & $\mathbf{0}$ \\
\hline Mean & 4.01 & 4.52 & 3.78 & 3.58 & & 2.69 & 2.94 & 2.56 & 2.34 & \\
\hline $\begin{array}{c}\text { For } \\
\text { comparing } \\
\text { the means } \\
\text { of }\end{array}$ & \multicolumn{3}{|c|}{$\operatorname{SEm} \pm$} & \multicolumn{2}{|c|}{ CD@ $9 \%$} & \multicolumn{3}{|c|}{ SEm \pm} & \multicolumn{2}{|c|}{ CD@ $9 \%$} \\
\hline $\mathbf{N}$ & \multicolumn{3}{|c|}{0.22} & \multicolumn{2}{|c|}{0.63} & \multicolumn{2}{|r|}{0.13} & & \multicolumn{2}{|c|}{0.38} \\
\hline $\mathbf{T}$ & \multicolumn{3}{|c|}{0.24} & \multicolumn{2}{|c|}{0.71} & \multicolumn{2}{|r|}{0.15} & & \multicolumn{2}{|c|}{0.43} \\
\hline $\mathbf{N} \mathbf{X} \mathbf{T}$ & \multicolumn{3}{|c|}{0.49} & \multicolumn{2}{|c|}{ NS } & \multicolumn{2}{|r|}{0.30} & & \multicolumn{2}{|c|}{ NS } \\
\hline
\end{tabular}

$\mathrm{N}$ : Nitrogen, T: weed management practices, $\mathrm{N} \times \mathrm{T}$ : Nitrogen and weed management practices $\mathrm{N}_{1}: 0 \mathrm{~kg} / \mathrm{ha}, \mathrm{N}_{2}: 75 \mathrm{~kg} / \mathrm{ha}, \mathrm{N}_{3}: 150 \mathrm{~kg} / \mathrm{ha}, \mathrm{N}_{4}: 180 \mathrm{~kg} / \mathrm{ha}$

$\mathrm{T}_{1}$ : Black and silver polythene mulch (40 microns), $\mathrm{T}_{2}$ : Paddy straw mulch, $\mathrm{T}_{3}$ : Pendimethalin $1 \mathrm{~kg} a . i / \mathrm{ha}+$ weeding 30DAT, $\mathrm{T}_{4}$ : Weed free control, $\mathrm{T}_{5}$ : Control (without weeding).

Fig.1 Effect of nitrogen levels, weed management practices and their interaction on weed control efficiency at 40 DAT of Gaillardia Cv. Local red (with yellow tip)

\section{$\mathrm{WCE} \%$}

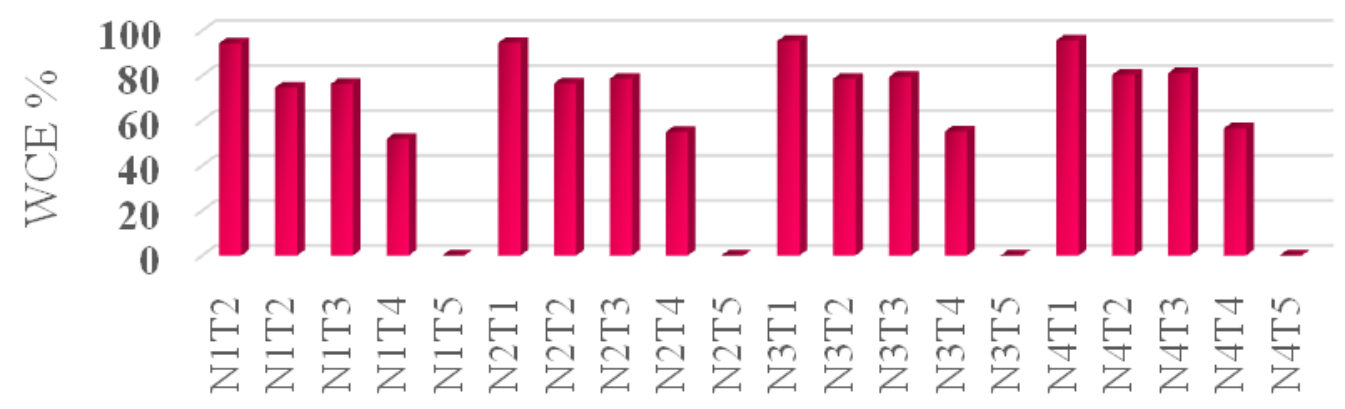

\section{Treatments}




\section{Dry weight of weeds (g)}

The data pertaining to dry weight of weeds at different stages of the crop growth was presented in Table 3.

\section{DAT}

At 20 DAT the treatment $\left(\mathrm{N}_{4}\right) 180 \mathrm{~kg} \mathrm{~N} / \mathrm{ha}$ $(3.58 \mathrm{~g})$ recorded minimum dry weight of weeds followed by $\left(\mathrm{N}_{2}\right) 150 \mathrm{~kg} \mathrm{~N} / \mathrm{ha}(3.78 \mathrm{~g})$ and both were on par with each other, and were significantly superior to all other treatments viz, $\left(\mathrm{N}_{1}\right) \quad 0 \mathrm{~kg} \mathrm{~N} / \mathrm{ha}(4.01 \mathrm{~g})$, $\left(\mathrm{N}_{2}\right) 75 \mathrm{~kg} \mathrm{~N} / \mathrm{ha}(4.52 \mathrm{~g})$. The highest dry weight was noticed in $\left(\mathrm{N}_{2}\right) 75 \mathrm{~kg} \mathrm{~N} / \mathrm{ha}(4.52 \mathrm{~g})$.

The observations recorded at 20 DAT, treatment $\left(\mathrm{T}_{1}\right)$ Black and silver polythene mulch $(1.98 \mathrm{~g})$ showed significantly lower dry weight of weeds than others which was followed by $\left(\mathrm{T}_{3}\right)$ pendimethalin @ $1 \mathrm{~kg}$ a.i. / ha + weeding 30 DAT $(3.39 \mathrm{~g}),\left(\mathrm{T}_{2}\right)$ paddy straw mulch recorded $(5.06 \mathrm{~g})$. In $\left(\mathrm{T}_{5}\right)$ control (without weeding) weeding was not done.

\section{DAT}

At 40 DAT least dry weight of weeds was noticed in $\left(\mathrm{N}_{4}\right) 180 \mathrm{~kg}$ nitrogen/ha $(2.34 \mathrm{~g})$ followed by $\left(\mathrm{N}_{2}\right) 150 \mathrm{~kg}$ nitrogen/ha $(2.56 \mathrm{~g})$ and both were significantly superior to other treatments viz, $\left(\mathrm{N}_{1}\right) 0 \mathrm{~kg}$ nitrogen/ha $(2.69 \mathrm{~g})$, $\left(\mathrm{N}_{2}\right) 75 \mathrm{~kg}$ nitrogen $/ \mathrm{ha}(2.94 \mathrm{~g})$. The highest dry weight of weeds was noticed in $\left(\mathrm{N}_{2}\right) 75 \mathrm{~kg}$ nitrogen/ha (2.94 g).

Data recorded at 40 DAT, treatment $\left(\mathrm{T}_{1}\right)$ black and silver polythene mulch $(0.71 \mathrm{~g})$ recorded lower dry weight of weeds and followed by treatment $\left(T_{3}\right)$ pendimethalin at $1 \mathrm{~kg}$ a.i. / ha + weeding 30 DAT $(3.02 \mathrm{~g}),\left(\mathrm{T}_{2}\right)$ paddy straw mulch $(3.13 \mathrm{~g})$ while $\left(\mathrm{T}_{4}\right)$ was recorded maximum $(6.33 \mathrm{~g})$ in weed free treatment.
There is no significant difference in the interaction effect of different levels of nitrogen and weed management practices on no. of weeds at 20 DAT and 40 DAT, weed control efficiency, dry weight of weeds.

On the basis of the results of the present investigation, it can be concluded that, among the nitrogen levels and weed management practices, application of $180 \mathrm{~kg} \mathrm{~N} / \mathrm{ha}$ and plots mulched with black and silver polythene mulch had good control over weeds and the plots under these treatments has good growth, highest flower yield with good quality flowers.

\section{References}

Armitage, A.M., 1992. Specialty Cut Flowers. Introduction to Floriculture, Larson, R.A. (Ed.). Academic Press, New York, 159-192.

Bailey, L.H., 1947. The Standard Encyclopedia of Horticulture. Macmillan Co., New York, USA.

Chawla, S. L. 2008. Response of African marigold to irrigation and mulching. Journal of Ornamental Horticulture, 11(2): 131-135.

Jadhav, S. B., Katwate, S. M., Kakade, D. S. and Pawar, B.G. 2018. Effect of pre and post emergence herbicides in rose weed management. International Journal of Chemical Studies, 6(5): 1583-1585.

Jenni, S., Brault, D. and Stewart, K.A. 2004. Degradable Mulch as an Alternative for Weed Control in Lettuce Produced on Organic Soils. ActaHort, Pp. 111- 118.

Kumar, S. and Chakraborty, B. 2010. Effect of different mulching materials in Rose. Journal of Ornamental Horticulture, 13(2): 95-100.

Mani, V.S., Malla, M. L, Gautam, K. C and Bhagwandas 1973. Weed killing chemicals in potato cultivation. Indian Farming, VXXII: 17-18. 
Shalini, M. and Patil, V.S. 2006. Effect of Different Methods of Weed Management in Commercial Growing of Gerberas. Karnataka Journal of Agricultural Sciences, 19(3): 746-748.

Sill WH, 1982. Weeds. Plant Protection, an Integrated Interdisciplinary Approach. Published by the Iowa State University Press. All rights reserved, composed and printed by the Iowa State University
Press, Ames. 74-79. Solaiman, A. H. M., Kabir, M.H., Uddin, A. F. M.J. and Asanuzzaman, H. M. 2008. Black plastic mulch on flower production and petal colouration of Aster (Callsitephus chinensis L. Nees). Am-Euras. J. Bot., (1): 05-08.

\section{How to cite this article:}

Prashamsha, G., P. Prasanth and Seenivasan Natarajan. 2019. Effect of Different Levels of Nitrogen and Weed Management Practices on Weed Parameters of Gaillardia (Gaillardia pulchella Foug.) under Hyderabad Conditions. Int.J.Curr.Microbiol.App.Sci. 8(10): 1173-1179. doi: https://doi.org/10.20546/ijcmas.2019.810.137 